\title{
The School We Want: Evolution or Change? A Consideration about Italian School
}

\author{
Carola Farci $^{1}$ \\ University of Padua, Italy \\ Email: carolaludovica.farci@phd.unipd.it
}

\begin{abstract}
This article is the result of an experimental research on the syllabuses that have been actually taught in Pisan high schools in the school year 2011-12. Highlighting four aspects heterogeneity, comparative studies, importance of Dante, importance of twentieth century literature I will attempt an analysis of the direction taken by Italian schools after the last educational reform and the remaking of school curricula.
\end{abstract}

Key words: Italian school, didactics of literature, schools' syllabuses

\section{Premises of the Analysis}

The didactics of literature represents an increasingly investigated and current field, whose analysis has become more and more urgent in Italy after the institution of the so-called TFA ${ }^{2}$. In September 2013, during the $\mathrm{ADI}^{3}$ conference in Rome, I gave a talk based on the analysis of texts examined in Pisa's high schools during the school years 2011-2012, which highlightened a strong heterogeneity in the schools' syllabuses for Italian literature, sometimes even among courses offered by the same school. This study aims to be a continuation of those initial graphs, a more detailed analysis, and above all an attempt to contribute to these years' thriving discussion.

I will start by summing up briefly my previous work, from which the current study moves on. I considered the texts read in five Pisan high schools (each specializing in either in humanities, foreign languages and socio-pedagogy, arts, and science with either an artistic or technical curriculum), for a total of 25 third years, 27 fourth years and 26 fifth years ${ }^{5}$. After a somewhat difficult recovery of the sources, that is the programs signed by both teachers and student representatives and handed in to the administrative office at the end of the school year, I proceeded to an analytic scan of the texts according to the following model.

\begin{tabular}{|c|c|c|c|c|c|}
\hline MANZONI & 1 & 2 & 3 & 4 & 5 \\
\hline In morte di Carlo Imbonati & & & $\mathrm{X}($ vv. $168-220)$ & & \\
\hline Cinque Maggio & $\mathrm{X}$ (With reference to Act IV from Adelchi) & & $\mathrm{X}$ & $\mathrm{X}$ & \\
\hline $\begin{array}{l}\text { L'utile per iscopo, il vero per } \\
\text { oggetto, l'interessante per mezzo }\end{array}$ & $\mathrm{X}$ & & $\mathrm{X}$ & & \\
\hline
\end{tabular}

\footnotetext{
${ }^{1}$ Dipartimento di Studi Linguistici e Letterari, Università di Padova, carolaludovica.farci@phd.unipd.it

2 TFA or Tirocinio Formativo Attivo (Educational Active Internship) is a one-year internship that allows participants to take the examination to become school teachers.

${ }^{3}$ ADI, Associazione Degli Italianisti, is the Italian Association for Italian Studies.

${ }^{4}$ The talk I refer to is available as the article: C. Farci (2014), "Come da programma. I Testi di Letteratura Italiana Analizzati nei Licei di Pisa", I Cantieri dell'Italianistica. Ricerca, Didattica e Organizzazione agli Inizi del XXI Secolo, conference proceedings of the XVII ADI Congress. 18-20 Sep. 2013, Rome Sapienza, edited by B. Alfonzetti, G. Baldassarri, E. Tomasi, ADI Editore, 2014. Retrived from http://italianisti.it/Atti-di-Congresso?pg $=$ cms\&ext $=$ p\&cms_codsec $=14 \& \mathrm{cms} \_$codcms $=581$.

${ }^{5}$ In Italy high schools last five years, the third year corresponds to an eleventh grade in the US, the fourth year to a twelfth grade and the fifth is the final one.
} 
After that I briefly scanned the data in order to visually sum up what percentage of classes read each author. I did not consider what had been read and how many texts from the same author had been taken into exam, but only what percentage of classes read each author. According to my analysis, it is not relevant whether the opera omnia or a single paragraph was read, but rather whether students had an introduction to a certain author or not. In fact, since this study focuses on texts, its meaning lies in the verification of a linguistic - and not only a thematic- familiarity for the students with the author. In order to understand the data processing, see the following graph ${ }^{6}$ :

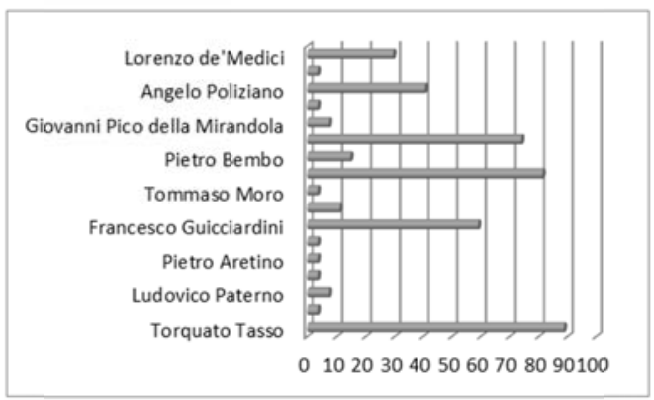

\section{$2 \quad$ Analysis of Data}

\section{$2.1 \quad$ Heterogeneity}

I have mentioned in the previous paragraph how the result from the sampled classies was heterogeneous. I now intend to extend my analyses ${ }^{7}$ by providing the reader with adequate charts. The following pie charts illustrate how many authors are read by all classes and how many by only one class every year (meaning the third, fourth and fifth year of high school). The authors read by a high number of classes are represented through a smaller slice because, as we will see, only very few authors are widely studied. The latter is represented with a lighter coloured slice, whereas the darker coloured ones refer to authors read by a smaller number of classes. Here is the graph relative to the third year of high school:

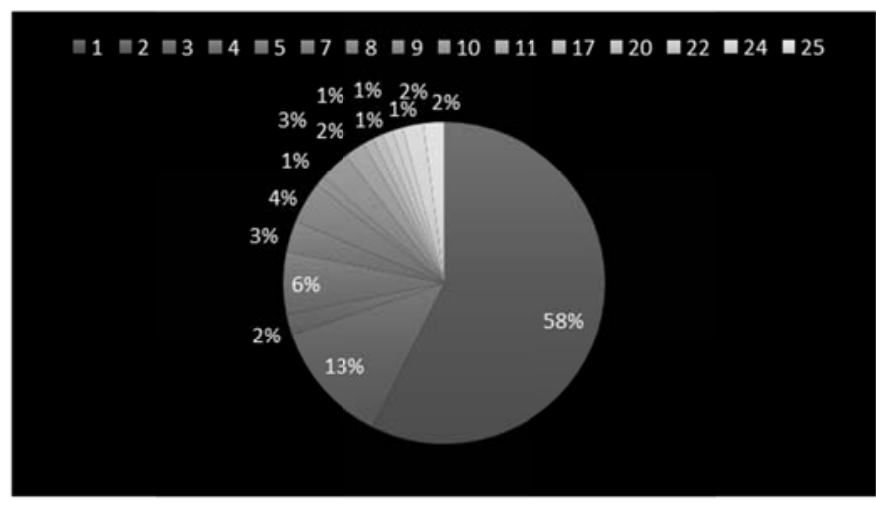

As you can see, $58 \%$, more than half of the authors, are only read by one class (see legend above). A significant $13 \%$ of authors only read by two classes follows. This means that $71 \%$ of authors are studied in less than two out of 25 third year classes. Therefore, three out of four of the authors in the syllabus are not studied by all the classes. Let us approach the issue from a different perspective: how many authors are read by all classes? According to the above chart, about $2 \%$ (the authors taken into exams

\footnotetext{
${ }^{6}$ For extensive graphs see: C. Farci (2014).

${ }^{7}$ Part of my considerations have been presented during "Letteratura per la scuola, competenze per la vita" [Literature for school, competences for life], a literature day that was celebrated in Pisa and simultaneously in many other Italian towns on 29/10/2014.
} 
were 98, therefore 2 authors), Dante and Guinizzelli ${ }^{8}$. As already highlighted in my previous article, only $88 \%{ }^{9}$ of all classes seem to have read a text by Petrarca. I was justifying this figure with the fact that the examined classes are the third years, whereas some teachers prefer to include Pretrarca at the start of the fourth year, to introduce Humanism. Boccaccio's (and Cavalcanti's) 96\% cannot be justified in the same way, and signifies that there are students who complete the third year without having approached Decameron. Approaching the podium, on the fourth position we find Francescio d'Assisi with 80\%, signifying two classes out of ten have not read Cantico delle Creature, and Jacopo da Lentini at 68\%. It is therefore not surprising that students are confused on the meaning of "sonnet". At $44 \%$ is Cecco Angiolieri, followed by Bernart de Ventadorn and Andrea Cappellano with 40\%. All other authors, around 90 names worthy of consideration, are attested under $40 \%$ - less than four out of ten classes.

The same applies to fourth year classes, where, however, we can see that no author is studied unanimously:

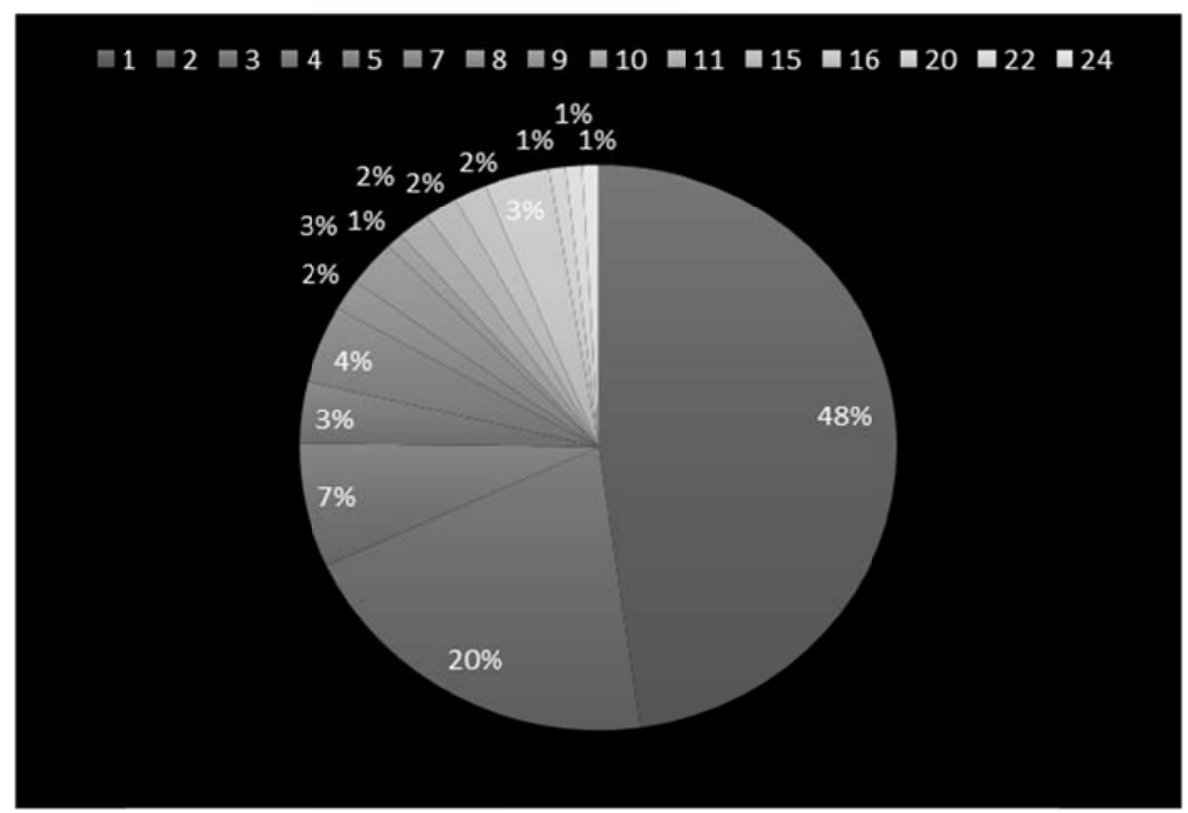

As stated above, the fourth year classes analysed are 27, but the graph shows us that only 24 classes studied the same author. This author is Torquato Tasso, leading our chart with $88 \%^{10}$ and followed by Ariosto with $81 \%$. Therefore, one student out of five does not read any excerpts from Orlando Furioso throughout the course of high school. In more than half of the examined classes we can see that Machiavelli (74\%), Dante, Guicciardini, Goldoni and Foscolo (59\%), and Parini (55\%) are studied. Only $40 \%$ of classes read a text by Poliziano or Galilei, while we can observe Marino at $37 \%$ with, significantly, Calvino. I say "significantly" because this data denotes the will to abandon a path that is exclusively chronological to focus on a more thematic approach instead. Calvino is in fact mostly read in relation to Ariosto, allowing the teacher to anticipate a part of twentieth century literature that, otherwise, would not - or would very unlikely - be touched upon. We will come back to this.

The other percentages from the fourth year classes are not particularly significant. Whether for the third year classes we observed a strong heterogeneity in the syllabus, for the fourth year classes we can even speak of fragmentation. This means that if a student switches to another class after the fourth year, he would most certainly have a very different background from his new classmates. To explain the above graph: $48 \%$ of the authors are read by one class, $20 \%$ by two, and so on.

Let us consider (see) the fifth year:

\footnotetext{
${ }^{8}$ See: C. Farci (2014).

${ }^{9}$ For authors to be associated with each percentage, see: C. Farci (2014).

${ }^{10}$ Data are rounded up without considering decimals.
} 


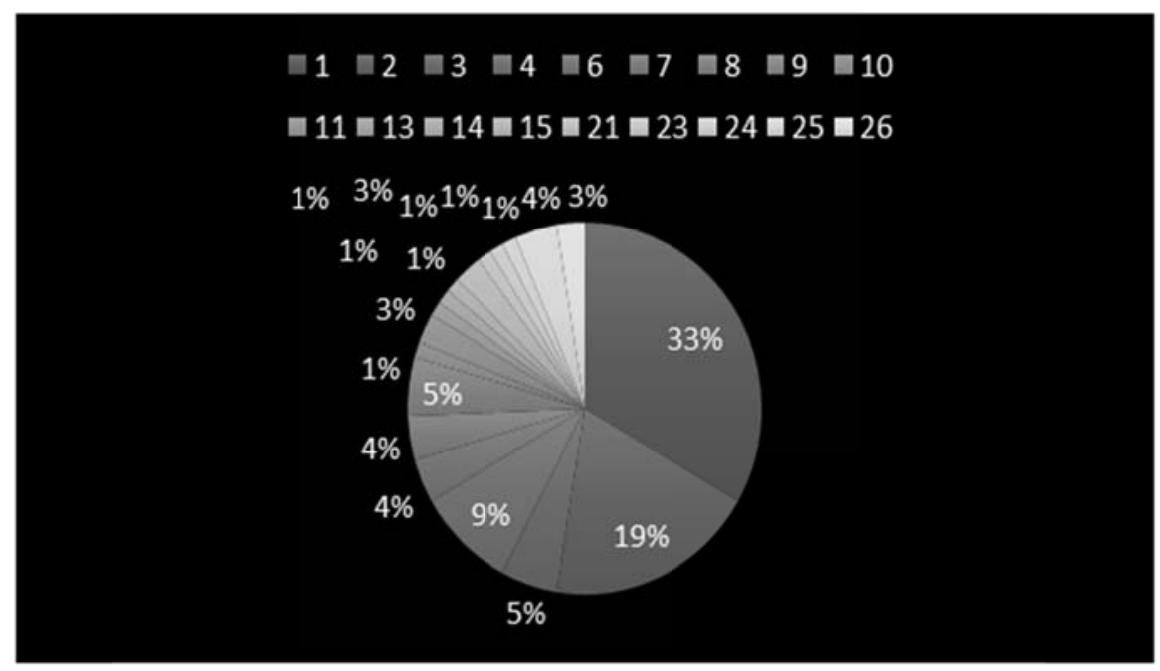

By reading the graph, it appears clear how the fifth year is, if not the most homogeneous class, at least the less heterogeneous. We see how $33 \%$ of authors are read by one class and $19 \%$ by two, slightly more than half of the pie, whereas the percentage of authors read by one or two classes was three quarters of the pie in third and fourth year classes. Moreover, some authors are read by all 26 classes taken into exam (Verga and Pascoli as represented by the largest slice in the graph). There are also a good number of authors read by $96 \%$ of classes, so 25 classes (D'Annunzio, Pirandello, Montale), followed by Svevo with $92 \%$ and Leopardi with $88 \%$. This is a particularly important data because the ministerial guidelines ${ }^{11}$ place Leopardi within the fifth year, that should otherwise be focused on the transition to the literature of the twentieth century and the investigation of this same literature. We will come back to this as well. For now, let us just notice how the number of authors studied overall has notably decreased: from 98 in the third year classes, to 112 in the fourth year and 78 in the fifth year.

We must come to the conclusion that, although there is strong heterogeneity throughout the whole three years, this decreases the closer students get to the completion of studies. It seems that there is a stable canon for the fifth year syllabuses that is followed by almost all classes ${ }^{12}$, whereas we observe a form of autarchy in the fourth year classes that causes the authors in common to be a very small number. This data can be interpreted in two different ways: heterogeneity can be extremely positive, as sign of great richness and variety, or extremely negative in regards to the practical difficulties of a student moving to a different school or facing the national entry test to a university. We must also consider a broader issue, starting from an ideological point of view: in the endl, school should form citizens of the same Country, voting for the same Parliament, who hopefully believe in the same constitutional values. Is it possible to provide a uniform education using such different programs? For now, it is a widespread opinion that yes, it is possible. Not only, it is desirable. The new didactics start from European guidelines from 2006 which consider eight Key Competences for Lifelong Learning:

- Communication in the mother tongue

- Communication in foreign languages

\footnotetext{
11"In ragione delle risonanze novecentesche della sua opera e, insieme, della complessità della sua posizione nella letteratura europea del XIX secolo, Leopardi sarà studiato all'inizio dell'ultimo anno." Indricazioni Nazionali, 2012. ["Due to the twentieth century resonance of his work, and to the complexity of his position in European nineteenth century literature, Leopardi will be studied at the beginning of the last year", National guidelines, 2012.]. Thereafter, the translation of all sources originally written in Italian (quotes, ministerial guidelines etc.) is mine.

${ }^{12}$ This figure seems to overtly contradict what has been written until now on twentieth century canon in high schools, of which scholars admitted the absence (see among others: U. M. Olivieri (ed.) (2001), "Un Canone per il Terzo Millennio". Bruno Mondadori). In fact, the contradiction is only partial. It is evident that the examined authors are less heterogeneous compared to other classes, but this is because, in reality, only a small part of twentieth century literature is actually studied, and only authors from the last decades of the nineteenth century and the first ones of the twentieth century being taken into exam. (see "The Twentieth Century" at the end of this article).
} 
- Mathematical competence and basic competence in science and technology

- Digital competences

- Learning to learn

- Social and civic competences

- Sense of initiative and entrepreneurship

- Awareness and Cultural expressions

Eventually, the competences we were used Eventually, the good old study of fundamental notions of literature (facts, dates, names, titles etc.), at times sadly mistaken for superficial knowledge by teachers and students alike, have given way to goals to achieve. The risk is that these macro-areas prove to be empty boxes to be filled with whatever we have and whatever we want rather than what is actually needed.

The argument implies important consequences. First of all, from the teacher's training's point of view which, with the reopening of TFA and the perspective of the qualification of teachers through high school leaving diploma alone, is more actual than ever. One need only think that TFA currently plans to dedicate more hours to pedagogic teaching than to disciplinary teaching. As a result, the kind of teachers we are preparing will be more likely to take care of the students' personality rather than of their disciplinary competence. A more than questionable choice $^{13}$, especially considering that the first can easily be protected through the latter.

The attention towards disciplinary competence should increase together with the teacher's autonomy, and therefore it should be -in the author's opinion- the main focus of the teacher's training. It goes without saying that the more autonomy teachers have, and therefore the more decisional power they have, the more accurate their disciplinary training should be. In order for a teacher to autonomously determine which authors their students will study, according to a personal criterion that includes some authors and excludes others, they should first of all know their subject in depth in order to be responsible enough to respond for their choice. This should be an obvious fact, which would not only preserve local literature, but also classes: as all teachers know, every class is different and has different needs. Nevertheless, it is necessary to keep in mind the other side of the coin. If, in order to (preserve) pay homage/privilege the local literature of Sardinia, for instance, Grazia Deledda were chosen as one of the compulsory authors to study, everyone would approve. However, if she were chosen over Pirandello, this would be a questionable decision regardless of context. And while Grazia Deledda is, after all, a Nobel prize winner, the priority could be given (and often is given) to less influential authors. There is in fact a general meaning, a value that us, as teaching and hermeneutic community, believe should be safeguarded. There are some authors we believe are fundamental ${ }^{14}$. Hence the intention of ministerial

\footnotetext{
${ }^{13}$ On the actual preparation of TFA teachers, see this interesting article: C. Carminati (2015, February), "Leopardi non era pessimista. Quello che sanno e non sanno i futuri insegnanti", Internazionale. Retrieved from http://www.internazionale.it/opinione/clizia-carminati/2015/02/02/leopardi-non-era-pessimista-quello-che-sanno-enon-sanno-i-futuri-insegnanti

${ }^{14}$ As Romano Luperini would say, although refering principally to the choices of twentieth century literature: "Se autonomia alle scuole significa far largo a qualche scrittore locale del Novecento (come suggerisce qualche indirizzo ministeriale) quando non si conoscono quelli dotati di valore nazionale e internazionale, ciò può solo accrescere il caos, la mancanza di vincoli comunitari, lo spappolamento delle società. L'autonomia ha senso solo se è sorretta da un punto di riferimento centrale" ["If schools' autonomy means to make room for local twentieth century authors (as some ministerial guidelines suggest) when students do not know the nationally and internationally influencial one, this could be a source of extra confusion, of loss of communal links, of the melting of society. Autonomy makes sense only if it is supported by a central reference system"], R. Luperini (2001), "La questione del canone, la scuola e lo studio del Novecento", Un canone per il terzo millennio, cit., p. 168. Again, Maria Teresa Sarpi, referring to the uncertainty of twentieth century canon as contemplated by older guidelines: "Non è da sottovalutare il pericolo degli spontaneismi troppo disinvolti nelle scelte dei docenti e soprattutto dello smarrimento di valori condivisi e della mancanza di senso dell'attività didattica in campo letterario per pratiche disorganiche, frammentarie, prive di valenza conoscitiva e formativa per la persona e per il cittadino, che hanno radici in questa comunità e in questa realtà storica" ["It is not to underestimate the risk of thoughtless spontaneous choices by the teachers, and especially the risk of losing communal values and the meaning of the didactics of literature in favor of disorganized, fragmentary politics, which lack educational and cognitive value for the person and citizen, who has root in this
} 
guidelines and the debate that followed due to the exclusion of authors, who, until then, had been canonical. The issue is that, being these indications absolutely generic, the authors' value is not preserved at all. It is an open discussion. So those who wrote the announcement for the teachers' examination in 2016 seem to disagree with the choices made by their colleagues in 2012, to the point where they include Vittorini and Carducci ${ }^{15}$ among the authors' future teachers should study, names not present in the guidelines for students. This could be justified if the teacher was well-prepared on a much wider range of authors, in order to handle the autonomy mentioned earlier. What cannot be justified is the opposite instance: Rebora and Meneghello were suggested by National Indications in 2012, but they were not included in the syllabus for teachers' examinations in 2016. Future teachers therefore must include in the program (as the Ministry states explicitly) two authors they were not required to know when they became teachers. A bizarre situation.

\section{$2.2 \quad$ About Dante}

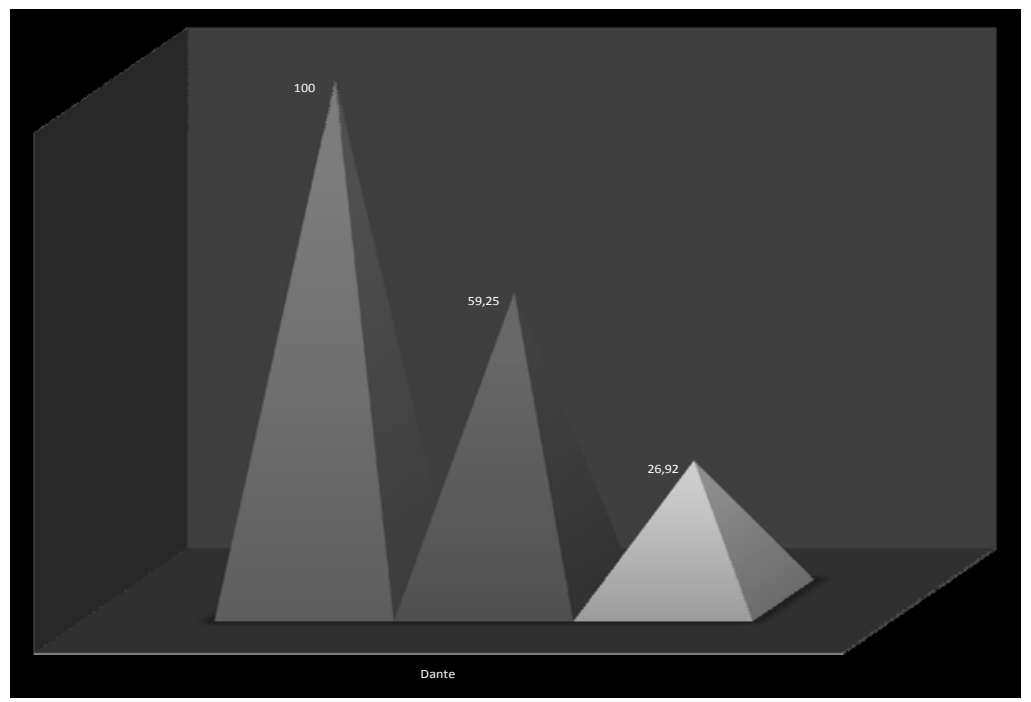

The graph shows that $100 \%$ of the third year classes read Dante, versus $59,25 \%$ of the fourth years and $26,92 \%$ of the fifth years. Year after year, students who read Divine Comedy diminish by a half. It is an important number if we consider that only the fifth year's program is required for passing the high school exam. It means three out of four students will not be examined on Divine Comedy. Needless to say, we are far from the 25 cantos National Indications suggest are covered throughout the three years ${ }^{16}$

community and in this historical setting"], M. T. Sarpi (2001), "La letteratura del Novecento a scuola", Un canone per il terzo millennio, cit., pp. 192-193.

${ }^{15}$ Exclusions that were decided in a not always peaceful climate. See for example the case of Carducci in L. Curti (2016), "Carducci nelle antologie e nel canone. Breve indagine su una cancellazione" in Antologie d'autore. La tradizione dei florilegi nella letteratura italiana, Atti del Convegno di Roma, 27-29 ottobre 2014, a cura di E. Malato e A. Mazzucchi. Roma, IT: Salerno Editrice, pp. 383-406.

${ }^{16}$ From National Guidelines 2012: "E dentro questo quadro, di descrizione e di analisi dei processi culturali - cui concorrerà lo studio della storia, della filosofia, della storia dell'arte, delle discipline scientifiche - che troveranno necessaria collocazione, oltre a Dante (la cui Commedia sarà letta nel corso degli ultimi tre anni, nella misura di almeno 25 canti complessivi), la vicenda plurisecolare della lirica (da Petrarca a Foscolo), la grande stagione della poesia narrativa cavalleresca (Ariosto, Tasso), le varie manifestazioni della prosa, dalla novella al romanzo (da Boccaccio a Manzoni), dal trattato politico a quello scientifico (Machiavelli, Galileo), l'affermarsi della tradizione teatrale (Goldoni, Alfieri)" ["it is in this frame of analysis and description of cultural processes - to which the study of history, philosophy, art history scientific disciplines will contribute - that teachers will make room for the following fields: Dante (at least 25 cantos in three years from Divine Comedy), the plurisecular tradition of lyrical poetry (from Leopardi to Foscolo), the great time of narrative epic poetry (Ariosto, Tasso), different manifestations 
(the data can be easily deduced: the classes that only read Divine Comedy in the third year cannot have read 25 cantos unless that was the only thing they studied at all).

To paraphrase Dante is not easy of course, and if Divine Comedy were more intelligible we would not have had eight centuries of glossaries specialised in it. The language used is difficult, especially in Paradise, certainly the most studied by that 26,92\%. This is why it should be featured in the exam, although it is certainly not easy to make room for great Dante, considering how many authors the fifth year students are required to read.

The discourse brings to a wider consideration on language. In an Italy where most children and teenagers do not read outside of school ${ }^{17}$, books in middle school and, incredibly, in high school, often report only paragraphed texts ${ }^{18}$. Not Dante or poets from the III century exclusively, but also relatively recent ones such as Manzoni are paraphrased. Unacceptable proposals, not only because it then becomes very hard, if not impossible, to instil the concept of "language matters" and diachronic variety, on which the National guidelines insist, in the student's mind; also because the method does not work: once more the problem is being avoided rather than solved with the proper strategy. It is a matter of principle if not only of method. It could be objected that historical texts are read in contemporary language in many other countries. My answer is: why should we always import the worst of other school systems? Teaching students to read in an historical language helps them to develop competences in problem solving; it helps them not to avoid an issue; it helps them to open their minds. It has become undoubtedly difficult to make students read an historical text. However, language is only partially the cause: students do not even read contemporary classics. A solution could be to introduce intermediate texts as part of a gradual process towards classics in the original language. It is a much harder path for both students and teachers, compared to choosing a text by Boccaccio translated into contemporary Italian, of course. It is also much fairer.

May I also be allowed to make another, this time strictly personal, reflection. When I was in middle school - less than fifteen years ago - we had to read the integral version of I Promessi Sposi in Manzoni's original language. Not only we were required to know five or six cantos from Inferno by heart, we also had to do a grammatical, logic and sentence analysis of some of Leopardi's Canti. Has the world changed this much, during the last fifteen years?

\subsection{Comparative Analysis}

As we have seen, knowledge of foreign languages is one of the competences suggested by Europe in 2006. Our students will be required to reach a B1 level in a chosen language by the end of their studies. Moreover, as a result of the reorganization of high schools in 2010, CLIL (Content and Language Integrated Learning) was introduced. This is just to add more technical data, since globalization and the formation of a supranational entity such as the European Union would be enough to imagine, as years go by, an increase in comparative studies. It is not so. We chose as a point of reference one of the most used manuals of Italian literature, Baldi-Giusso ${ }^{19}$, specifically the volume that is chronologically closer to us, in its 2012 and 1994 editions. We find two chapters dedicated to foreign literature in the most recent

of prose, from short stories to novels (Boccaccio, Manzoni), political and scientific treaty (Machiavelli, Galileo), theatre (Goldoni, Alfieri)"].

${ }^{17}$ See: R. Giovannini (2016, May 09), "Metà dei ragazzi italiani non ha letto neanche un libro al di fuori della scuola", La Stampa. Retrieved from http://www.lastampa.it/2016/05/09/societa/met-dei-ragazzi-italiani-non-haletto-neanche-un-libro-al-di-fuori-della-scuola-neAVu9Mwlq1XXd4abFH07K/pagina.html

${ }^{18}$ Also Clizia Carminati signals the problem: "Deve, insomma, [il docente universitario] obbligare gli studenti a confrontarsi con il testo, il che significa confrontarsi con un intero la cui struttura spesso è portatrice di significato, e confrontarsi con usi linguistici che possono risultare oggi poco familiari. Ma senza far perdere la coscienza che di lingua italiana si tratta: in Italia non dovrebbe esistere (purtroppo, invece, esiste) un'edizione del Principe di Machiavelli con 'versione in italiano moderno' a fronte" ["[The professor] should force students to face the text, that is facing with a text body whose structure often carries meaning, and face linguistic customs that may be unfamiliar to contemporary speakers. All this without losing awareness of the fact that this is still Italian. In Italy we should not have (but unfortunately we have) editions of Machiavelli's Principe with a contemporary Italian translation"], see: C. Carminati (2015, February).

${ }^{19}$ Baldi G., Giusso S., Razzetti M., Zaccaria G. (1994 e 2012), "Dal testo alla storia, dalla storia al testo". Paravia. 
one: the first located in the first part of the twentieth century, the second after Montale. They examine, respectively: Thomas Mann, Franz Kafka, Marcel Proust, James Joyce, Robert Musil, Virginia Woolf, Ernest Hemingway; and Jean-Paul Sartre, Albert Camus, George Orwell, Jerome David Salinger, Jorge Luis Borges, Gabriel Garcia Marquez. In the 1994 edition, on the other hand, we find a first paragraph dedicated to European avant-garde, featuring Vladimir Mayakovski, Guillaume Apollinaire, Tristan Tzara, Andrè Breton; in the chapter dedicated to "writers in between the two wars", we can find a special section dedicated to Thomas Mann, Marcel Proust, James Joyce, Franz Kafka, Ernest Hemingway, Ezra Pound, Thomas Stearns Eliot; followed by "writers after WWII", Jean-Paul Sartre, Albert Camus, Bertolt Brecht, Samuel Beckett, Jorge Luis Borges. Some authors differ, but the substance does not. It is, of course, not the only instance.

This is likely due to the fact that current National Guidelines and previous ones, seem rather confused on the topic. While totally absent in the second biennium, there is a hint to comparative studies for the fifth year only:

At the core of the syllabus should be authors and texts whose influence on the innovation of forms and genres between XIX and XX century was deeper, and that marked the paths along which poetry and prose would redefine their canons during the XX century. From this perspective, the happenings of poetry, which cannot be reduced to national issues, cannot but move from the work of Baudelaire and from the Italian reception of European symbolism which in Baudelaire has its roots. ${ }^{20}$

Therefore, the decision lies once again in the teacher's hands. We will now observe the role of foreign literature in the classes we examined.

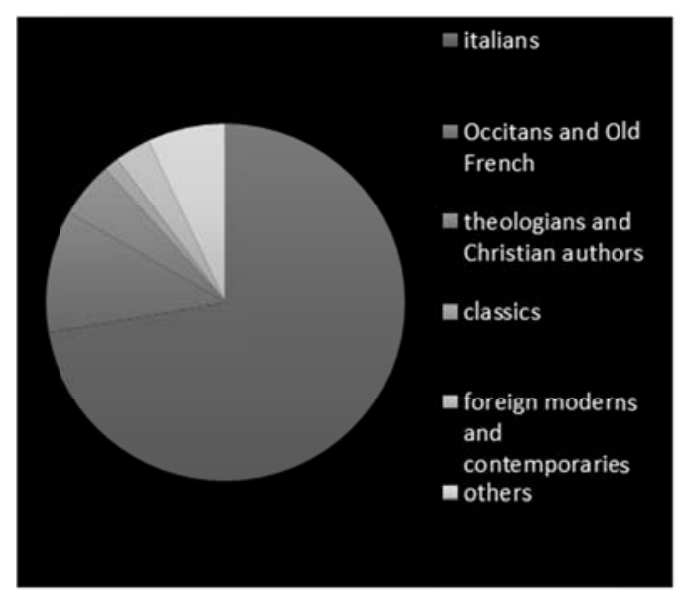

\footnotetext{
${ }^{20}$ National Guidelines, 2012. [Al centro del percorso saranno gli autori e i testi che più hanno marcato l'innovazione profonda delle forme e dei generi, prodottasi nel passaggio cruciale fra Ottocento e Novecento, segnando le strade lungo le quali la poesia e la prosa ridefiniranno i propri statuti nel corso del XX secolo. Da questo profilo, le vicende della lirica, meno che mai riducibili ai confini nazionali, non potranno che muovere da Baudelaire e dalla ricezione italiana della stagione simbolista europea che da quello s'inaugura.]
} 

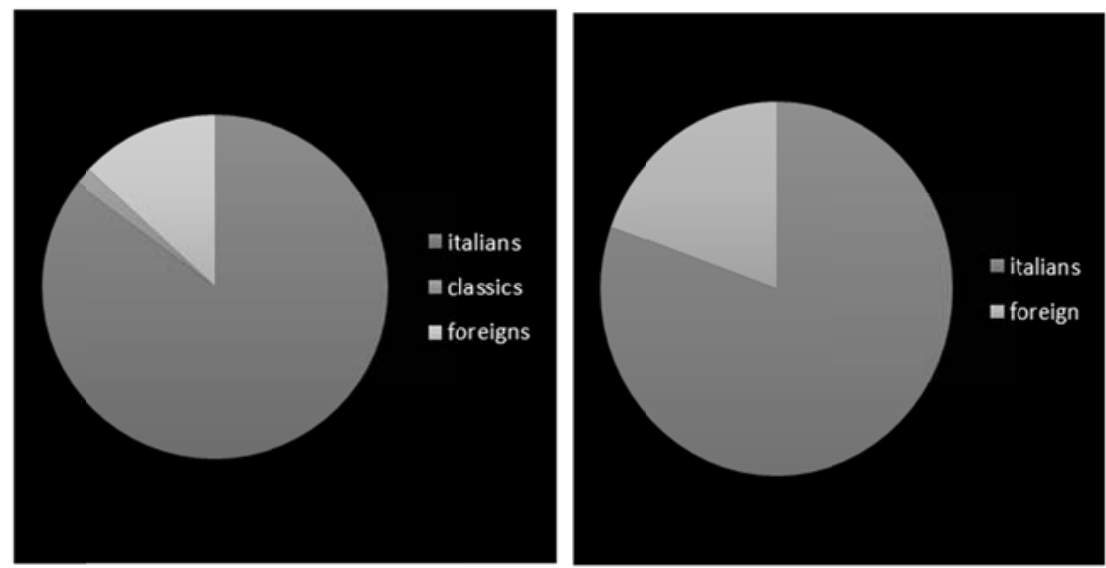

The third-year class is, from a comparative point of view, the most complex to analyze. The lack of a national, or canonized, language in the analyzed period, does not allow to create a neat distinction between what is local and what is foreign. Consider, for instance, all the authors who, despite having been born and bred in the territory that will become Italy, have written in Occitan, or in Latin, etc. In the above graph, both those who wrote in Vulgar and their contemporaries who wrote in Latin are under "Italian". The difference with the archaic language is in the term "classics", to distinguish a fifteen-century literary work in Latin (under "Italian") from an excerpt by Virgilio. The denomination "Occitan and Old French" also follows the same criteria: a Tuscan author who wrote in Occitan is considered "Italian", whereas his French counterpart is included in the other category. Again, I recommend looking at the graphs in the previous article for a direct comparison of the authors taken into consideration ${ }^{21}$. However, I will give an example of the various categories: "Italian" ( $72 \%$ in total) includes Dante, Cavalcanti, etc; "Occitan and Old French" (11\%) Bernart de Ventadorn; "Theology and Christian authors" (5\%) Sant'Agostino; "classics" (2\%) Euripide, Virgilio, etc; "foreign modern and contemporary" (3\%) authors such a Bertolt Brecht, highlighting a thematic path; lastly, the category "other" (7\%) includes all the authors who could not be catalogued in one of the above, yet could not create a new ad hoc group, such as for One Thousand and One Nights and Ali-al-Ballanubi. This seemed the best differentiation in order to analyse our third, fourth and fifth-century authors and the literary world they are compared to diachronically and synchronically.

A diachronic analysis is also present in the fourth-year class, since there is a slice of classical authors constituting amount to $2 \%$, versus a $13 \%$ of authors we consider 'foreign", so contemporaries of different nationality.

Lastly, the fifth-year class has the strongest delimitation: $80 \%$ of Italian authors, and $20 \%$ of foreign authors, contemporaries of the Italians that were taken into exam.

It is complex to enter a debate on what would be the right percentage of foreign authors to study. It should be noted that we live in an era where the global has invaded national frontiers, severely questioning them. We only need to think to the situation in Italy and in the rest of Europe; simply and more generically, to globalization, low cost companies that allow travelers to reach the other side of Europe more cheaply than if they were to visit a city next to their own, the Internet connecting us to the other side of the world in tenths of a second. Therefore, it can be pointed out how, especially in the last class, that should embrace the contemporary, it is fundamental to reserve ample space for comparison with foreign literature, or at least some established world known authors. These are valid observations, to which one could validly object that in order for the student to deal with other cultures in an open and correct way, they should have a clear vision of their own culture, and that to direct them towards an international canon is the foreign literature teachers' job. To this regard, it would be a good idea to follow Francesco Orlando's advice: "At school, in a utopian school of course, we should teach notions of European or better said Western literary history, with a focus on Italy; and we should read both Italian works on which to develop the literary meaning of texts, works of another literature in a determinate foreign language, and works of yet other literary traditions in translation. There is no

\footnotetext{
${ }^{21}$ See: C. Farci (2014).
} 
incompatibility among the three approaches" ${ }^{22}$. However, as stated by the scholar, this could only happen in a utopian land, where the clock ticks more slowly, and lessons are not compromised by strikes, holidays and sick leaves.

\subsection{The Twentieth Century}

One of the biggest problems of school disciplines, especially for what concerns horizontal knowledge, is that the amount of material to study, as time passes by, increases, but the available time to study it, does not. As this happens with History, Philosophy, Art History, it is often necessary to skip contemporaneity, for the simple reason that there are not enough hours available, unless the program from previous years is drastically reduced. This is a problem of extraordinary relewance, and it takes us back to the reflection on canon which was tackled by many scholars before ${ }^{23}$.

One of the strategies found by teachers in order to deal with twentieth century literature is to anticipate it through thematic paths. An example of this was seen with Ariosto and Calvino, but there are numerous alternatives. The risk is that of losing sight of the chronological frame (in Marchiani's words, "the risk of a compression of the historical dimension" ${ }^{24}$ ), fundamentally important for students who do not navigate the centuries autonomously yet, in addition to the risk of anticipating texts students cannot analyze for lack of historical tools. A banal example is the case of Fenoglio: by anticipating him to the third year, or the fourth year, his historical context is lost, a context that students will hardly remember from middle school.

In order to observe the presence of these thematic paths, we included the graphs relevant to the third and fourth year, not only (the Novecento), but also the whole of the period that cannot be chronologically reached. We therefore establish to study Machiavelli and Ariosto at the end of the third year, a goal which only few classes achieve, and the study of Leopardi at the end of the fourth and start of the fifth class, as recommended by the Ministry ${ }^{25}$. The authors named function as a divide between a chronological and a thematic path, of which we can examine the extent in the following graphs:
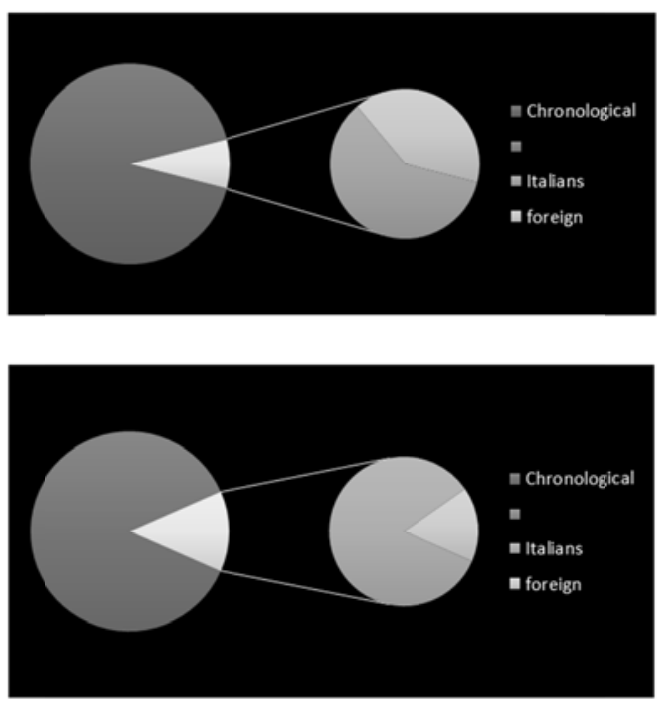

\footnotetext{
${ }^{22}$ F. Orlando (2001), "Teoria della letteratura, letteratura occidentale, alterità e particolarismi", Un canone per il terzo millennio, cit., p. 87 ("A scuola, beninteso nella scuola del paese di utopia, si potrebbero dare nozioni di storia letteraria europea, o meglio occidentale, a dominante italiana; e leggere, con dosaggi vari, sia testi italiani su cui sviluppare il senso letterale del testo, sia testi di un'altra letteratura nella lingua statutariamente studiata, sia in traduzione testi di altre letterature ancora. Tra i tre tipo di approccio non esiste nessuna incompatibilità").

${ }^{23}$ See again: U. M. Olivieri (ed.) (2001).

24 "Il rischio di una compressione della dimensione storica", L. Marchiani (1997), "I percorsi tematici, strumento didattico per lo studio della letteratura e per l'attualizzazione dei testi", Allegoria, 26, pp.70-71.

${ }^{25}$ See note 12 .
} 
The percentage is not very high, especially in the third year class. We tried to make a further differentiation between Italian and foreign thematic path. A thematic path is in fact often part of a more global vision of literature, sometimes requiring comparative studies. This allows to draw attention to one figure: the foreign authors included in the thematic path of the third year class are about double the number of those included in the fourth year class, regardless of the general minor importance that is given to thematic development. The tendency, as we will see in the next graph, is confirmed in the fifth year classes as well, where the percentage of foreign authors in our (Novecento) is halved, making it an almost exclusive Italian Novecento.

The discourse changes in the last year, where we no longer talk of a chronological or thematic paths, but of a percentage of XX-century authors studied. It will be helpful for this purpose to remember what the National Guidelines say:

Considering the XX-century resonance in his work, and of the complexity of his position in European XIX-century literature, Leopardi shall be studied at the start of the last year. Always resorting to a real multidisciplinary program, the historical outline, that will cover from the Unification of Italy to the present day, establishes that the student is able to comprehend the relation of the literary system (genres, themes, styles, relationship with audience, new expressive methods), on one side with the course of events that bit by bit modified the social and political layout in Italy, on the other side with the phenomena that characterize modernity and post-modernity, both in and outside Europe. At the core of the syllabus should be authors and texts whose influence on the innovation of forms and genres between XIX and XX century was deeper, and that marked the paths along which poetry and prose would redefine their canons during the XX century. From this perspective, the happenings of poetry, which cannot be reduced to national issues, cannot but move from the work of Baudelaire and from the Italian reception of European symbolism which in Baudelaire has its roots. The influence of Pascoli and D'Annunzio on twentieth century literature makes them fundamental to study; as much as, for what concerns prose, the representation of the "real" in Verga and the breakdown of the novel in Pirandello and Svevo constitute crucial moments in the "tradition of Novecento".

In the XX century and until now, the study of poetry, that will decisively start with Ungaretti, Saba and Montale, will contemplate an adequate knowledge of texts chosen among contemporary and subsequent lyric (for instance Rebora, Campana, Luzi, Sereni, Caproni, Zanzotto...). The study of prose, from neorealism to the contemporary period, will comprehend readings from significative authors such as Gadda, Fenoglio, Calvino, P. Levi, and can be integrated with other authors (for instance Pavese, Pasolini, Morante, Meneghello). ${ }^{26}$

${ }^{26}$ National Guidelines, 2012, "In ragione delle risonanze novecentesche della sua opera e, insieme, della complessità della sua posizione nella letteratura europea del XIX secolo, Leopardi sarà studiato all'inizio dell'ultimo anno. Sempre facendo ricorso ad una reale programmazione multidisciplinare, il disegno storico, che andrà dall'Unità d'Italia ad oggi, prevede che lo studente sia in grado di comprendere la relazione del sistema letterario (generi, temi, stili, rapporto con il pubblico, nuovi mezzi espressivi) da un lato con il corso degli eventi che hanno modificato via via l'assetto sociale e politico italiano e dall'altro lato con i fenomeni che contrassegnano più generalmente la modernità e la postmodernità, osservate in un panorama sufficientemente ampio, europeo ed extraeuropeo. Al centro del percorso saranno gli autori e i testi che più hanno marcato l'innovazione profonda delle forme e dei generi, prodottasi nel passaggio cruciale fra Ottocento e Novecento, segnando le strade lungo le quali la poesia e la prosa ridefiniranno i propri statuti nel corso del XX secolo. Da questo profilo, le vicende della lirica, meno che mai riconducibili ai confini nazionali, non potranno che muovere da Baudelaire e dalla ricezione italiana della stagione simbolista europea che da quello s'inaugura. L'incidenza lungo tutto il Novecento delle voci di Pascoli e d'Annunzio ne rende imprescindibile lo studio; così come, sul versante della narrativa, la rappresentazione del "vero" in Verga e la scomposizione delle forme del romanzo in Pirandello e Svevo costituiscono altrettanti momenti non eludibili del costituirsi della "tradizione del Novecento".

Dentro il secolo XX e fino alle soglie dell'attuale, il percorso della poesia, che esordirà con le esperienze decisive di Ungaretti, Saba e Montale, contemplerà un'adeguata conoscenza di testi scelti tra quelli di autori della lirica coeva e successiva (per esempio Rebora, Campana, Luzi, Sereni, Caproni, Zanzotto, ...). Il percorso della narrativa, dalla stagione neorealistica ad oggi, comprenderà letture da autori significativi come Gadda, Fenoglio, Calvino, P. Levi e potrà essere integrato da altri autori (per esempio Pavese, Pasolini, Morante, Meneghello).”. 
Following the Ministry's suggestion, we chose the work of Pascoli and D'Annunzio as a divider in the following graph, considering the following perfectly in line with MIUR's guidelines. However, as we verified, these remain largely ignored.

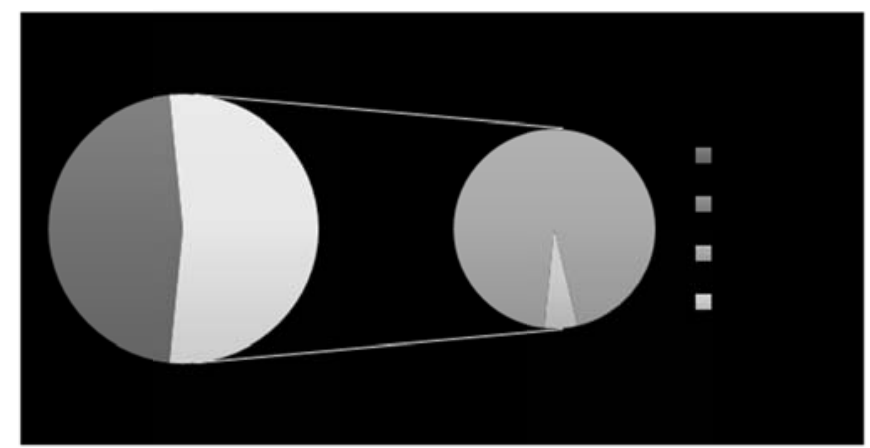

Only half of the analyzed authors in the fifth year belong to (Novecento), whereas the other half is still being occupied by XIX century authors and the debate between classics and romantics.

It is now necessary to make a distinction within the XX century. If we observe the reading data for each author, for which we once again recommend to consult the graph in the previous article, we notice how the historical period in between Pascoli and Montale is rich in readings by students, but the following one is rarely considered. Below are the data showing the percentage of classes that read each author from the second half of the XIX century in Pisan high schools:

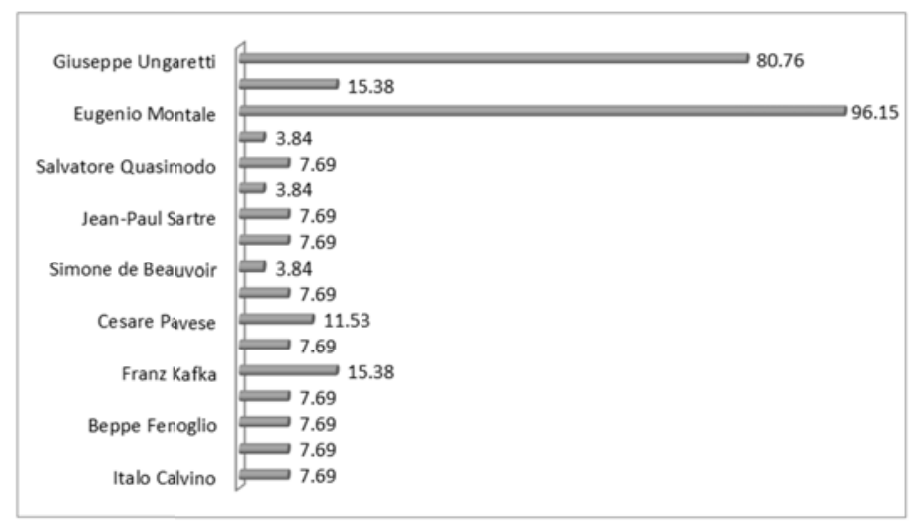

The twentieth century presents itself as a half century, where the divide is Montale, last author read by a great majority of the classes ${ }^{27}$.

What stands out is the void that follows; following authors are read by a few - sometimes very fewclasses. Yet, Pisa is a happy example. We tried to focus our study on Montale, only changing our geographical area of interest in Italy. We confronted the data from a high school specialized in the humanities in Pisa with the data from the same type of high school, Siotto Pintor in Cagliari, obviously from the same school year. This is the result:

\footnotetext{
${ }^{27}$ Martina Bianchi, discussing her thesis in 2013-14, confirms this figure. Bianchi used the model I provided for Pisa, and applied it to the last year in Lucca's high schools, reaching the same conclusions as me. See: M. Bianchi (20132014), "La didattica della letteratura italiana del Novecento. Uno studio sul campo: i programmi e i manuali dei licei della provincia di Lucca", Thesis for the bachelor course in Italian Language and Literature, academic year 2013-14, University of Pisa.
} 


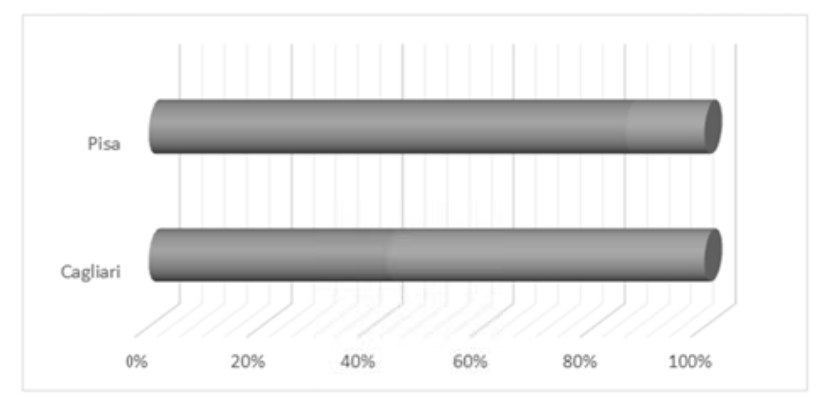

If almost all of the classes in Pisa read Montale, less than half of the classes in Cagliari did. Where did the students who did not reach Montale stop? At Svevo and Pirandello, who correspond more to the start of the twentieth century than to the actual twentieth century. According to this figure, which is very incomplete but very alarming at the same time, the Ministry's guidelines are very far from reality, especially in some areas of Italy. It would be interesting to discover where the program stops in realities such as rural centers or cities with particular social issues.

The data regarding Montale, divider of the first and second (Novecento) first and second halves of the twentieth century, takes us to an interesting reflection. Which authors have been chosen for the end-ofyear exam in the last few years? Here they are:

- 2010: Primo Levi (1919 - 1987)

- 2011: Ungaretti (1888-1970)

- 2012: Montale (1896 - 1981)

- 2013: Magris $(1939-\ldots)$

- 2014: Quasimodo (1901 - 1968)

- 2015: Calvino (1923 - 1985)

- 2016: Eco (1932 - 2016)

As a result, students whose program stopped at Svevo and Pirandello did not have the chance to face the first part of the exam, and if they did, the credit for this belongs only to their own personal competences, not those developed in class. If in cases such as Magris' and Eco's it is possible that the student did not have to study the author in order to do the exam, this cannot be said of authors such as Primo Levi, Ungaretti, Montale, etc. who, constituting a fundamental part of our literary heritage and being part of National Guidelines ${ }^{28}$, must be considered part of the national exam ${ }^{29}$.

The scholastic point of view is neither the sole nor the most important one. Without diminishing the importance of other historical periods, the second half of the twentieth century is certainly a dense, fascinating literary period. In addition, the language used is close to that of the students, so that they can approach contemporary texts with relative ease. It is often complained that students do not read.

\footnotetext{
${ }^{28}$ See note 26 .

${ }^{29}$ On this point see Mariateresa Sarpi, who perfectly described the situation analyzed so far, despite referring to a different period from the one we considered: “《Questo Saba noi non l'abbiamo fatto, non so nemmeno chi è.» Così ha dichiarato più di uno studente intervistato dal solito giornalista all'uscita dalla scuola, dopo la prima prova scritta dell'esame di stato dell'anno scolastico 1999-2000. Tra le tracce proposte figurava l'analisi di una poesia di Saba. L'affermazione fa venire in mente almeno un paio di riflessioni: innanzitutto che i ragazzi non provano neppure ad avvicinarsi a un testo di un autore che non sia stato oggetto di uno specifico studio scolastico, riflettendo indirettamente una preparazione più contenutistica che metodologica; poi che ancora oggi, nonostante l'ampia produzione critica su uno scrittore e la sua riconosciuta importanza nella letteratura del Novecento, il canone scolastico può assegnarli una presenza marginale o ignorarlo del tutto nella programmazione" [" «I don't even know who this Saba is supposed to be, we didn't study him at all». This is what many students stated when interviewed by journalists outside of the school, after the first written session of the 1999-2000 school-leaving examination. Among the possible literary topics to analyze was a poem by Saba. The students' statement should lead us to reflect: first of all, students do not even try to deal with an author whose work has not been analyzed in class, reflecting a more topical that methodological education; secondly, even today, despite the amount of scholarship produced on an author and his acknowledged importance in twentieth century literature, the canon of schools can marginalize or even ignore him at all."], M. Sarpi (2001), p. 174.
} 
That they do not read books. That they do not buy them, spending their time watching TV instead of scrolling through the pages of a novel. Although we cannot generalize, this is a credible scenario ${ }^{30}$. Let us wonder, then, if reading texts closer to them, in both language and content, could help some potential readers to approach literature. Potential readers who would remain so, maybe even after school, maybe after university. And this should not substitute other readings, less close to students and maybe linguistically complex (such as highly entertaining but hard to understand Orlando Furioso), but only be a new path for those who already fell in love with literature during their school years, and a last hope for those who did not. Who says that someone who reads Una Questione Privata might not autonomously decide to pick up Ariosto?

As Luperini states:

"The study of (Novecento) is fundamental in order to better understand the great authors of the past, to ask them the most current, culturally stimulating questions. The problem is not quantitative but qualitative. To study (Novecento) means to acquire the sensitivity and culture of contemporaneity and be able to look at the past through the point of view and intellectual questions of the present. This does not mean just adding more authors, but studying those of the past from a different perspective. To study (Novecento) means to review the whole literary heritage from the perspective, the horizon of values, the urgency of the present, not to flatten it on contemporaneity or to just emphasize analogies, but also to be able to appreciate and value the differences. ${ }^{31}$

\section{References}

1. G. Baldi, S. Giusso, M. Razzetti, G. Zaccaria (1994 and 2012), "Dal testo alla storia, dalla storia al testo". Paravia.

2. M. Bianchi (2013-2014), "La didattica della letteratura italiana del Novecento. Uno studio sul campo: i programmi e i manuali dei licei della provincia di Lucca", Thesis for the bachelor course in Italian Language and Literature. University of Pisa, 2013-2014. Unpublished.

3. C. Carminati (2015, February), "Leopardi non era pessimista. Quello che sanno e non sanno i futuri insegnanti", Internazionale. Retrieved from http://www.internazionale.it/opinione/clizia-carminati/2015/02/02/leopardi-nonera-pessimista-quello-che-sanno-e-non-sanno-i-futuri-insegnanti.

4. L. Curti (2016), "Carducci nelle antologie e nel canone. Breve indagine su una cancellazione in Antologie d'autore. La tradizione dei florilegi nella letteratura italiana", in Atti del Convegno di Roma, 27-29 ottobre 2014, a cura di E. Malato e A. Mazzucchi. Salerno Editrice, pp. 383-406.

5. C. Farci (2014), "Come da programma. I Testi di Letteratura Italiana Analizzati nei Licei di Pisa", in I Cantieri dell'Italianistica. Ricerca, Didattica e Organizzazione agli Inizi del XXI Secolo, conference proceedings of the XVII ADI Congress. 18-20 Sep. 2013, Rome Sapienza, edited by B. Alfonzetti, G. Baldassarri, E. Tomasi. ADI Editore. Retrived from

http:/ /italianisti.it/Atti-di-Congresso?pg $=$ cms\&ext $=$ p\&cms_codsec $=14 \& c m s \_c o d c m s=581$.

6. R. Giovannini (2016, May 09), "Metà dei ragazzi italiani non ha letto neanche un libro al di fuori della scuola", La Stampa. Retrieved from http://www.lastampa.it/2016/05/09/societa/met-dei-ragazzi-italiani-non-ha-lettoneanche-un-libro-al-di-fuori-della-scuola-neAVu9Mwlq1XXd4abFH07K/pagina.html

7. R. Luperini (2001), "La questione del canone, la scuola e lo studio del Novecento", in Un canone per il terzo millennio. Bruno Mondadori.

\footnotetext{
${ }^{30}$ See: R. Giovannini (2016, May 09).

${ }^{31}$ See: Luperini R. (2001), pp. 166-167. ("Lo studio del Novecento è fondamentale proprio per meglio capire i grandi autori del passato, e cioè per porre loro le domande più attuali e culturalmente più stimolanti. Il problema, insomma, non è quantitativo, ma qualitativo. Studiare il Novecento deve voler dire anzitutto acquisire la sensibilità e la cultura della contemporaneità e poter traguardare il passato attraverso il punto di vista e la problematizzazione intellettuale del presente. Non si tratta solo di aggiungere degli autori, ma di studiare in modo diverso quelli del passato. [...] Studiare il Novecento vuol dire rivedere tutto il patrimonio letterario dalla prospettiva, dall'orizzonte di valori, dalle urgenze del presente, non per appiattirlo sulla contemporaneità o per porre in risalto solo le analogie, ma anche per poter apprezzare e valutare le differenze".)
} 
8. L. Marchiani (1997), "I percorsi tematici, strumento didattico per lo studio della letteratura e per l'attualizzazione dei testi", in Allegoria, 26, pp.70-71.

9. U. M. Olivieri (ed.) (2001), "Un Canone per il Terzo Millennio". Bruno Mondadori.

10.F. Orlando (2001), "Teoria della letteratura, letteratura occidentale, alterità e particolarismi", in Un canone per il terzo millennio. Bruno Mondadori.

11.M. T. Sarpi (2001), "La letteratura del Novecento a scuola", in Un canone per il terzo millennio. Bruno Mondadori. 